\title{
International-Cultural Communication of the Saman Dance Performance by Indonesian Students in Nanjing
}

\author{
Dani Fadillah ${ }^{a, 1, *}$, Zalik Nuryana ${ }^{b, 2}$, Muhammad Sahuddin ${ }^{c, 3}$, Dong Hao ${ }^{\mathrm{d}, 4}$ \\ ${ }^{a}$ Department of Communication Science, Universitas Ahmad Dahlan, Jl. Kapas No.9, Semaki, Kec. Umbulharjo, Kota Yogyakarta, Daerah Istimewa \\ Yogyakarta 55166, Indonesia \\ ${ }^{\mathrm{b}}$ Department of Islamic Education Universitas Ahmad Dahlan, Jl. Kapas No.9, Semaki, Kec. Umbulharjo, Kota Yogyakarta, Daerah Istimewa Yogyakarta \\ 55166, Indonesia \\ c School of Education, Nanjing Normal University, No. 1 Wenyuan Road Qixia District, Nanjing, P.R, China 210046 \\ ${ }^{\mathrm{d}}$ School of Communication and Journalism, Nanjing Normal University, No. 1 Wenyuan Road Qixia District, Nanjing, P.R, China 210046 \\ ${ }^{1}$ dani.fadillah@comm.uad.ac.id*; ${ }^{2}$ zalik.nuryana@ pai.uad.ac.id; sahuddin@yahoo.co.id; ${ }^{3} 180201002 @$ stu.njnu.edu.cn ${ }^{4}$ \\ * corresponding author
}

\section{ARTICLE INFO}

Article history

Received 2019-11-28

Revised 2019-12-10

Accepted 2019-12-19

Keywords

Culture

International Communication

Saman Dance

\section{ABSTRACT}

This study aims to find out how Indonesian students in China can become ambassadors to introduce and promote Indonesian names in a cultural frame. Saman dance, which is a typical dance of the people of Aceh, can be performed well by Indonesian students even though, on average, those who become dancers are not Aceh residents. This research is field research, where the author follows and observes Indonesian students while they are performing Saman. The results of this study show that foreign nationals abroad welcomed the saman dance performed by Indonesian students in China.

This is an open-access article under the CC-BY-SA license.

\section{Introduction}

Saman dance is a Gayo Tribal dance that is usually performed to celebrate important events in custom (adat). The poetry in the saman dance uses the Gayo language. Besides, this dance is often also performed to celebrate the birth of the Prophet Muhammad. In some literature mention, saman dance in Aceh was founded and developed by Sheikh Saman, an ulama who came from Gayo in Southeast Aceh. UNESCO designated the saman dance as a Representative List of Intangible Cultural Heritage of Humans in the 6th Session of the Intergovernmental Committee for the Protection of UNESCO Intangible Cultural Heritage in Bali, 24 November 2011 [1]. This dance is unique through dance movements, and validity has a universal philosophy and the power of transmission to the community. Therefore, making it one of the traditions of the Indonesian nation that is recognized by UNESCO in addition to wayang, keris, batik, and also angklung musical instruments. Such is the explanation of the meaning, function, and uniqueness of the saman dance. Now, by reading the description above, it is hoped that you can open your horizons about this dance originating from Aceh. Indeed not only the duty of the Acehnese to preserve this art. However, it is our duty together as citizens of Indonesia to protect the culture of this saman dance.

In addition to its aesthetic value, this dance is a portal of oneness between the hamba (servant), and Allah (God). On the one hand, it becomes social guidelines in daily life. Poems from kalamullah are followed by the message of preaching often inserted; more precisely, there must be, in this dance. Spiritual elements of religious concepts in it make this dance sacred, even considered mystical by some people [2]. If you listen carefully, there are greetings and tahlil sentences in the array spoken by saman dancers. For example, "mmm иo lesa, mmm иo lesa, иooo lesa, uo lesa, lesalamaalaikum," or, "hmmm lailalaho, hemmm lailalaho, lahoyasare hala lemha halaya hele 
lemha hele." As a communal expression, saman dance contains an organized symbol system of the Gayo community social system. The presentation contributes and becomes an alternative media in reconstructing the dynamics of social and cultural life. Saman is an identity of culture and religion for Aceh peoples have any challenges [3].

In the dance, there is the poem, "ike a peut koere gere kueten keh geh peh I ukere gakiko." That is, even if you drift, I did not pick up, because, when I came to the bumpkin first, you did not rebuke. This poem recalls the importance of not being arrogant towards others. Pride will only have the effect of suffering on oneself. Saman dance is a dance that needs teamwork. Usually played as a place to convey advice, messages, or propaganda. This dance depicts religion, education, manners, heroism, togetherness, and cohesiveness; in religion science, this is called tazkiyatun nafs [4]. Before starting this dance, a traditional leader representing the local community delivered useful and useful advice to the players and the audience of the surrounding community. The players consist of young women or men wearing local traditional clothing. This dance is better known to foreign people compared to Pendet or Kecak dance from Bali. Though only displaying applause and other movements such as shaking, dazed, kirep, and strain that makes it look unique compared to other dances [5]. Uniformity and harmony between the players are essential in presenting this dance. Therefore, players are required to concentrate fully and practice seriously to produce beautiful dances and amaze anyone who sees it. From various types of dances in Indonesia, saman dance has its uniqueness. Of course, this uniqueness can be the main attraction of this saman dance performance. Here are some of them (1) hand movements as a companion; (2) men and women as players; (3) unique formation; (4) harmony between dancers; (5) as dakwah media; (6) diverse costumes or clothing [6].

Saman dance generally does not use the help of musical instruments in large ensemble format to accompany the show. However, it only uses sounds that come from the dancer itself. The sounds of music were created from a combination of the dancers' songs added to the sound of clapping from dance movements, for example, through applause, the sound of hands tapping on the thighs with a very fast tempo, and displays episodes of virtuosic body percussion [7]. However, some performed it using musical instruments such as rapa' $i$ played by dance leaders. It could also be through the sounds made by the players themselves. Besides, he shouted in the middle of the dance as a sign of movement changes. Saman dances are generally only played by young men. But along with the development of the era began many saman dancers from women. Initially, it was also only played by young men who numbered around ten people. Eight people act as players, and two people act as cues. Over time and in this modern era, saman dance has developed. Now it can be staged in various formal and informal events. The number of players is also more than ten, and women are allowed to play it, which was previously not permitted. Dance actions that are so harmonious with the presentation of poetry create an atmosphere of joy and admiration by many people. This dance is performed by dozens or dozens of odd numbered sons. Saman Gayo dance is usually danced by 13, 15 , even up to 21 male dancers. The number of dancers tends to be limited in order to avoid the difficulties faced by nemah lagu in stabilizing the movement. Lagu referred to here is motion, because it calls motion in the Gayo language is Lagu. Thus, nemah lagu means the leader of the motion [8].

The unique and different movements of other traditional dances make it a condition of cohesiveness and harmony between dancers. Dancers are required to focus more on each dance move. Besides, dancers must still recite poems or singing. Cohesiveness and harmony must be carried out correctly in performing this dance. It only shows applause and other movements such as shaking, dazing, keep, and strain that makes the saman dance look unique compared to other dances. Uniformity and harmony between the players are essential in presenting this dance. Therefore, players are required to concentrate fully and practice seriously in order to produce beautiful dances and amaze anyone who sees it. From various types of dances in Indonesia, this dance has a unique meaning. The uniqueness can be seen from the movements of the players and the harmony between the song and the accompanying movements. This dance is generally used as a medium for conveying advice and preaching the teachings of the Islamic religion. The admonitions and propaganda were conveyed through the lyrics of the songs to be sung by the dancers. The lyrics are generally used in Arabic and Acehnese. In addition to singing that contains the message of preaching and advice, the singing of the same dancers can also be a satire. Also, it has a meaning of high courtesy, teaching or education, heroism, and cohesiveness of the people of Aceh. Therefore 
before the start of this dance performance, there is an opening that contains advice, messages, or preaching given by the master smart or commonly called syekh. This shows that humanity in the Holy Qur'an has a duty of dakwah to become kaffah [9].

Clothing or costumes used by dancers, namely using traditional clothing which is generally brightly colored with simple decorations on the head. Three parts of the costume are used namely, the head in the form of bulung teleng, attached to the body filigree clothes, blemishes, and cloth gloves or fingers. In addition to that, there is a mask on the hand and a handkerchief. Costumes for the head are quite simple, and this is different when looking at saman in Aceh. On the head, young dancers wear very complicated costumes, adorned with layers of colorful fabrics, flowers and tiaras. There are many ornaments, which are attached to the head covering of the dancers, they also place a wig above their hair to lift the head covering about 15 centimeters [10]. The dance from Nanggroe Aceh Darussalam, saman, has always been a mainstay of Indonesian students who appear in the international arena. Like when the International Cultural Day is often held by universities that have many international students in China. Thousands of spectators who attended the international cultural day did not blink watching the saman players' smart movements, which consisted of Indonesian students. The speed and accuracy of the dynamic movements of saman have always been a unique attraction for foreign citizens.

International Cultural Day itself is a regular exhibition and is an annual program at various universities in China. This festival is a series of various activities, including culinary bazaars, art exhibitions, sports, as well as folk art and music performances. In addition to displaying local art, the event also featured traditional arts from various parts of the world by bringing in artists from their home countries - for example, Indonesia, Hungary, Bosnia Herzegovina, Philippines, Macedonia, New Zealand, and others. However, with saman, it seems that Indonesia has become the most popular among the arts of other countries. Figure 1 is a saman dance performance at International Cultural Day in Nanjing city.

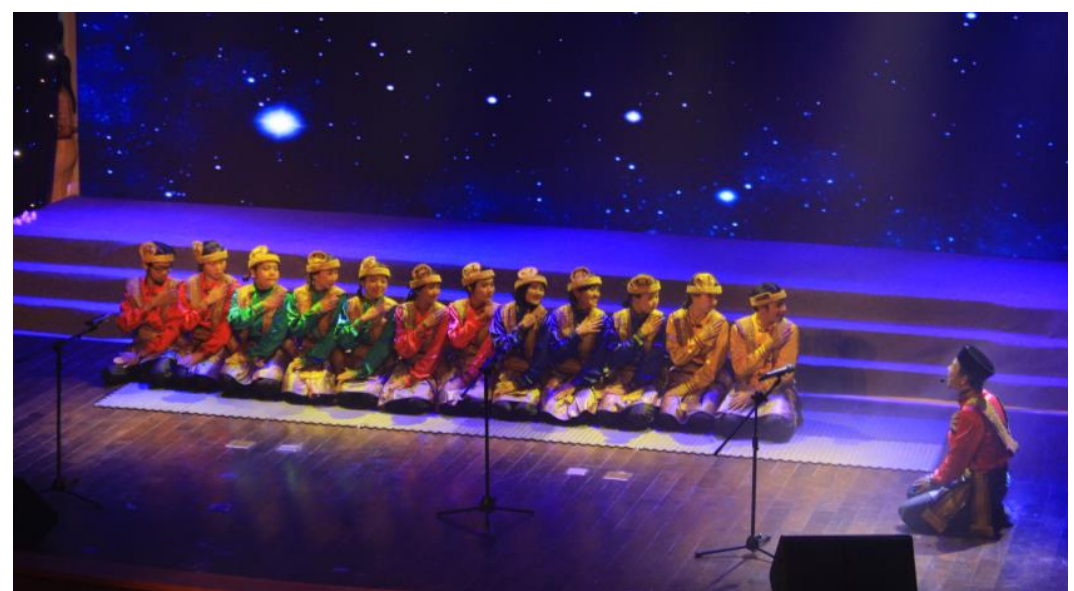

Fig. 1.Saman Dance Performance by Indonesians Students in International Cultural Day Nanjing

Efforts to preserve saman dance in Indonesia continue to be carried out both at the regional and national levels by the district/provincial government and relevant ministries/state institutions. One way is to regenerate Saman dancers in China. Even though, in reality, the problem now is not the dancer regeneration because there are so many Indonesian students coming to China to study, the problem is the lack of people who are ready to become saman trainers in China.

\section{Theoretical Framework}

\subsection{International Communication}

As a field of study, International Communication focuses attention on the whole process through which data and information flow through national borders. Also, international communication is associated with many political concepts and relations of one country with another country or several other countries [11]. The subject studied is not just the current itself, but also the structure of the current that is formed, the actors involved in it, the means used, the effects it creates, and the underlying motivation [12]. International communication activities can take place between people to 
people or government to government. Strictly speaking, international communication is also the study of various kinds of Mass Mediated Communication between two or more countries with different cultural backgrounds. The background differences can be in the form of differences in ideology, culture, economic development, and language differences [13]. At the beginning of its development, international communication focused on the study of information and the flow of messages delivered from one country to another. However, with the development of the era, the focus of the study of international communication began to move towards propaganda, and an international paradigm called Free and Flow Information emerged [14]. This paradigm discusses many issues and studies on globalization, privatization, media imperialism, and the information age in the international sphere, and many occur in various countries [15].

Like other sciences and studies that continue to experience development, the study of international communication also has developments towards the Global Communication Order or also called "New World Communication and Information System." This study arises from the premise that Free Flow Information does not have a free and balanced flow of information that should be by its name, due to the tendency of information in particular countries [16]. The Global Communication Order enables countries to communicate more broadly and dynamically, coupled with technological advances that further facilitate the ongoing communication process. The focus of the study of international communication is no longer merely a matter of politics and security but instead covers broad and global issues that are a common concern or thoughts such as performing arts. Besides having a focus of study, international communication also has its function. The following are some functions of international communication in their application, (1) Build and strengthen international relations between countries by increasing cooperation and avoiding various conflicts, both conflicts between one country and another, and governance conflicts with the people of a nation; (2) Building dynamism of relations between states and establishing good relationships at the international level by covering studies and focus in various fields and groups of people in each state and between countries; (3) Acting as a supporter of the implementation of good and quality foreign policy in the countries involved in carrying out their interests with one another.

\subsection{International Communication Perspective}

Diplomatic Perspective, this perspective commonly done interpersonal or small groups (small groups) through diplomatic channels; direct communication between state officials to facilitate or resolve conflicts, support bilateral or multilateral relations, expand political influence, international forums at the UN level or regional forums, or even at diplomatic meetings such as state dinners [17]. Journalistic Perspective is associated with mass media. Because of the flow of information about developed countries, there is international communication in this perspective, developed countries, also used by developed countries as a means of control over the power. This journalistic path is also often used for propaganda purposes to change state policies and objectives or weaken the position of the opposing state [18]. Propaganda Perspectives, it is designed to instill commitment into the minds of other countries' communities and be encouraged to support activities to improve, feel, and strengthen, sponsored, or developed in the morning of adjusting certain countries. Propaganda is a potent instrument to exert influence [19].

\section{Method}

This research is field research. The term field study is a term that is often used in conjunction with ethnographic research [20]. The authors also explained that field research is also often called ethnography or participant observation research. However, according to Harrison, ethnography is only an extension of field research. Ethnography redefines how field research must be carried out. According to Roice Singleton, field research comes from two related traditions, namely anthropology and sociology, where ethnography is an anthropological study, and ethnomethodology is a study of sociology [21]. Ethnography provides answers to the question of whether the culture of an individual group, while ethnomethodology offers solutions to how people understand their daily activities so they can behave in socially acceptable ways. Field research is a qualitative study in which researchers observe and participate directly in small-scale social research and observe local culture. Many students are happy with field research because they are directly involved in the association of several groups of people who have a unique attraction. There is no scary math or 
complicated statistics, no abstract deductive hypothesis. Conversely, there are social interactions or face to face with "real people" in a particular environment [22].

In fieldwork, researchers individually talk and observe directly the people being researched. Through interaction over several months or years of learning about their neighbors, their life history, their habits, hopes, fears, and dreams. Researchers meet new people or communities, develop friendships, and discover new social worlds; this is often seen as fun. However, field research is also time-consuming, emotionally draining, and sometimes physically dangerous [23]. When should we use field research? Field research is conducted when research questions include learning about, understanding, or describing the interactions of a group of people. This is usually done if the question is: What about people in the social world? Or What is the social world of $\mathrm{X}$ ? This can be used when other methods (for example, surveys, experiments) are considered impractical. Douglas stated that some of what social researchers want to learn could be learned only through the direct involvement of a researcher in the field [24]. A simple method of field research observations (Field Research) can be defined that is directly conducting observations to obtain the information needed in the preparation of final research. For example, when researchers want to examine how the role of opinion leaders in the Kajang tribe, it uses the field research method to obtain accurate and precise results, where researchers come to live, socialize and carry out other social activities in order to get conclusions that are appropriate from what is in the field. Therefore, this research was conducted by the author following the routines of Indonesian students who are actively becoming ambassadors of Indonesian culture at every opportunity, especially when they will carry out saman dance performances. There the author collects various information needed to write this research report.

\section{Results and Discussion}

At the event that was held at Nanjing Normal University, Jiangsu Province, China, dozens of Indonesian students from various backgrounds and regions from Indonesia played the role of saman dancers, displaying their prowess in front of guests, the majority of whom were international students, professors, and figures local figures. They are endlessly amazed by the movements for the saman dance movement that are attractive, high dynamics, and accompanied by poetry in the Acehnese language. Although the dancers are not $100 \%$ of the original land of the saman Dance, Gayo Lues, Aceh Province, their movements are very charming. They only had time to do the exercises two months before the show, although some of them had previously performed several performances as part of a series of Indonesian cultural diplomacy missions abroad, such as the annual routine festival that was often held in Shanghai. As shown in figure 1.

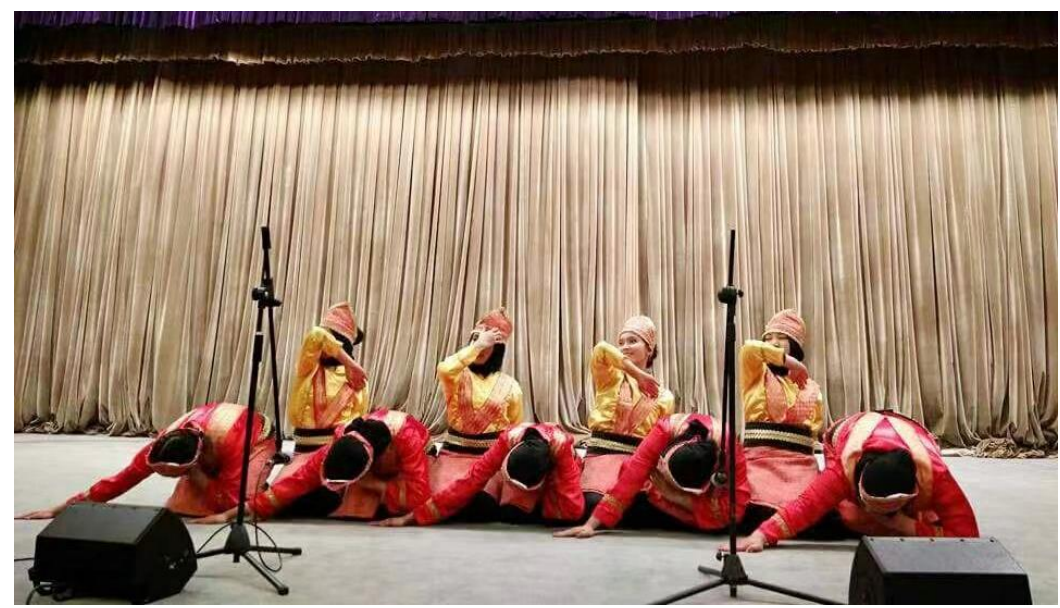

Fig. 2.Saman Dance Performance by Indonesian Students in Chinese New Year

According to Sundoro, a saman dance coach for Indonesian students in Nanjing, the saman dance is a symbol of togetherness, despite its high dynamics. We must maintain harmony on earth. That sentence refers to the hope of the world community that International Culture Day can encourage and encourage the creation of peace that is full of harmony in various parts of the world. One senior Aceh resident in the city of Nanjing, Muhammad Sahuddin, explained the meaning of each saman movement, and Gayo Lues's typical clothing to the purpose of the saman Dance representing the spirit of solidarity and unity, something that all global citizens must continue to do. 
To realize the goal of togetherness and cohesiveness in the saman dance performance, it is necessary to practice continuously before the show takes place, in Figure 3 is the situation of preparation for the performance.

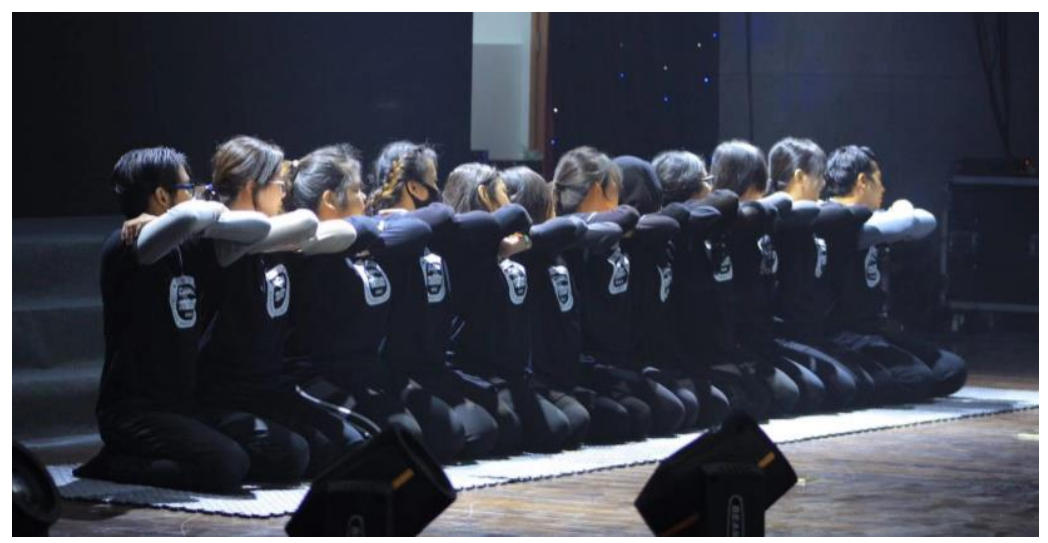

Fig. 3. Indonesian Student Training for Performance

The success of the Saman Dance diplomacy on International Cultural Day is inseparable from the cooperation of various parties. After performing on International Cultural Day, the Saman dancers usually continue their trips to various local and national level shows in China at the request of the local authorities. At the event, they also had a chance to teach some people about the basic movements of the Saman Dance, which were challenging to follow and learn. Figure 4 is the saman dance performance at the Indonesian cultural festival.

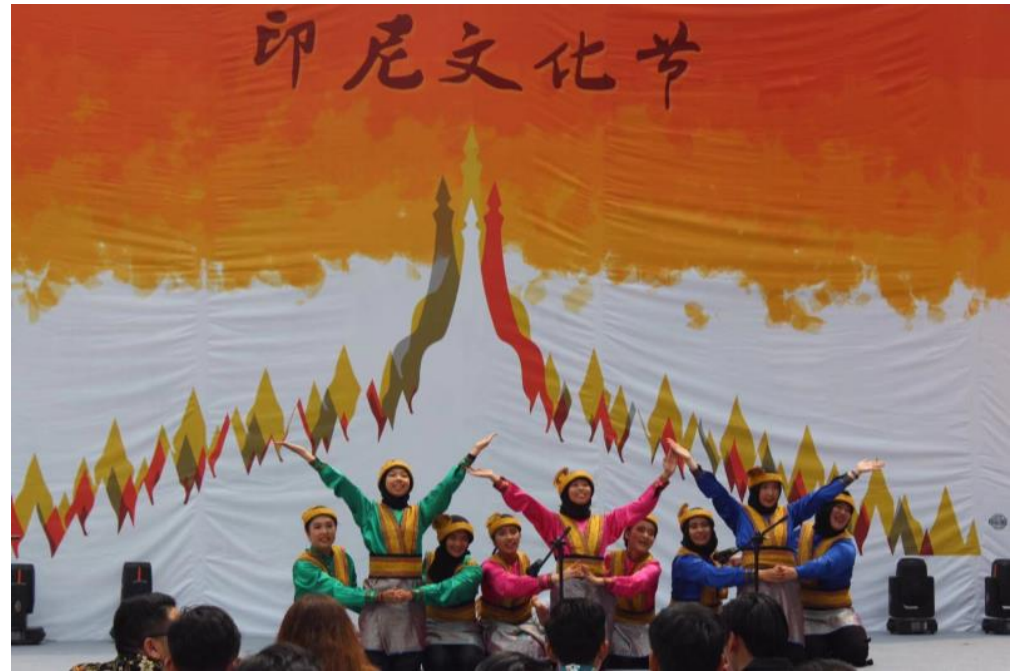

Fig. 4. Indonesian Students performance for Indonesia Festival

Through this cultural diplomacy, the international community is expected to be increasingly aware of the saman Dance, which has beautiful movements and is rich in philosophical values. For information, saman Dance has been inscribed in the list of UNESCO's Masterpieces of Oral and Intangible Heritage of Humanity since 24 November 2011, which urges it to be preserved (in need of urgent safeguarding). The role and activity of Indonesian students further strengthen bilateral relations between the two countries through so-called people to people contact, part of the concept of Total Diplomacy, namely diplomatic efforts undertaken by non-governmental elements unofficially. Alternatively, other terms are Cultural Diplomacy, Exchange of ideas, information, values, systems, traditions, beliefs, and other aspects of culture, to foster mutual understanding. Cultural diplomacy is one part of public diplomacy which is currently being intensified by the Indonesian government as a step that not only the government can actively cooperate with foreign countries but elements or private actors and civil society as in this case Indonesian students aim at introducing Indonesian culture and are expected the value of mutual respect, peace and harmony is achieved. Amid their limitations as students, they independently and cooperatively realize their wishes in introducing Indonesia, an expression of the spirit of love and pride of Indonesian students 
to their countries that deserve great support and appreciation from all of us and current policymakers. The involvement of cultural issues in international relations often remembered for the performance of arts such as art visits or art weeks to foreign countries.

If further, we will find that cultural relations in international relations can be more than that. It can be said that the problems of international relations are mostly cultural issues. Just as we interact with our fellow human beings, to interact with other countries, we need a cultural understanding so that the process of friendship or cooperation can take place smoothly. Thus, to understand, to know the habits, customs, restrictions, taboos, preferences, ordinances of a country's inhabitants, are expected to minimize the offense that may arise in communicating. Thus, cultural understanding becomes very important in the association of International Relations. The understanding of this culture can be seen in the Protocols of the Protocol or the ordinances governed by the meetings, for example, the language of the Protocol negotiations, where the procedures of respect, greeting, Speaking opinions, asking, asking proposals arranged and guided in such a way. Cultural understanding is necessary for the success of negotiations or cooperation. Cultural relations and other international relations can be expressed within the framework of cultural diplomacy. In this regard, diplomacy as one of the studies of international relations, not only interpreted as negotiations (negotiation) only but also how to manage relations between nations both in a state of peace and (especially) in the situation of war.

Therefore, cultural diplomacy can be presented from things that are micro-nature where culture can be considered as things that smell the arts, but also up to a macro-based study that considers the management of inter-relationship People indeed involve cultural aspects in the broadest sense. In the end, some things can be noted that the application of real cultural diplomacy can be made by anyone (for Indonesia is possible with what is known as multi-track diplomacy), must be integral, and Synergize with foreign policy and other programs coordinated by the Department of State. The success of cultural diplomacy is determined by the factors of economic strength, political authority, and military power and the consistency of its implementation because the objective of cultural diplomacy is the establishment of opinions. Therefore, cultural diplomacy will often be instrumental and relevant to be implemented by developed countries that have the power to support its diplomatic.

\section{Conclusion}

Indonesian students in China have successfully played their roles as agents of Indonesian cultural diplomacy for the international world. Stunning performances resulting from a fusion of dances with excellent taste, collaborated with a unified movement by the dancers succeeded in making the world's eyes dazzle. For the next few years, it seems that Indonesia will not run out of talent from Saman dancers in China due to a large number of young seeds that have dancing talent. The problem is who will hone these hidden talents. To date, saman's trainers are active in China, especially in the city of Nanjing, which is very limited. In the city of Nanjing, there is only one active saman dance trainer left, and he will return to Indonesia after 2021, whereas there is still no figure to replace him.

\section{References}

[1] M. Kartomi, "The Saman Gayo Lues Sitting Song-Dance and its Recognition as an Item of Intangible Cultural Heritage," Yearb. Tradit. Music, no. 45, pp. 97-124, 2013.

[2] M. Kartomi, "Aceh's Body Percussion: From Ritual Devotionals to Global Niveau," in Music and Ritual, Semar Publishers Srl, 2006, pp. 85-106.

[3] A. Rahman and Z. Nuryana, "Islamic Identity and Transitional Democracy in Indonesia: Ideology, Public Sphere and Domination," 2019.

[4] A. Ghofar, U. Abubakar, and M. Azhar, "Tazkiyatun Nafs As a Strength Base of Teacher Personality Competency," IJISH (International J. Islam. Stud. Humanit., vol. 1, no. 2, p. 128, Feb. 2019.

[5] R. Restela and T. Narawati, "Tari Rampoe Sebagai Cerminan Karakteristik Masyarakat Aceh," Panggung, 2017. 
[6] Y. Heniwaty, "Saman Dance of The Aceh People: Identity and Actualization," J. Community Res. Serv., vol. 2, no. 1, pp. 184-191, 2018.

[7] M. Kartomi, "The Development of the Acehnese Sitting Song-Dances and Frame-Drum Genres as Part of Religious Conversion and Continuing Piety," Bijdr. tot taal-, land-en volkenkunde/Journal Humanit. Soc. Sci. Southeast Asia, vol. 166, no. 1, pp. 83-106, 2010.

[8] Y. Heniwaty, R. H. D. Nugrahaningsih, I. Harahap, and M. Liyansyah, "Gerak Tari Saman dalam Bentuk Notasi Tari,” Balai Pelestarian Sejarah dan Nilai Tradisional Banda Aceh, Medan, 2011.

[9] A. Abdullah, S. Masruri, and K. Bashori, "Islamic Education and Human Construction in The Quran," Int. J. Educ. Learn., Jun. 2019.

[10] M. A. Ishiguro, "Gifts from the Waves? Cultural Identity, the Rise of Performing Arts Communities, and Women's Performance Practice in Post-tsunami Aceh,” Asian Music, vol. 50, no. 2, pp. 90-121, 2019.

[11]D. Fadillah, L. Zhenglin, and D. Hao, "Social Media and General Elections in Malaysia 2018 and Indonesia 2019,” J. Komun. ISKI, vol. 4, no. 1, pp. 1-8, 2019.

[12]L. Camaj Phd, "International communication," in An Integrated Approach to Communication Theory and Research, Third Edition, 2019.

[13]K. Hallahan, D. Holtzhausen, B. van Ruler, D. Verčič, and K. Sriramesh, "Defining Strategic Communication," Int. J. Strateg. Commun., 2007.

[14]K. Jaya, "Venezuela's communication dynamics in rejection of humanitarian assistance from United States of America," Int. J. Commun. Soc., vol. 1, no. 1, pp. 26-33, 2019.

[15]T. M. Steinfatt and D. M. Millette, "Intercultural communication," in An Integrated Approach to Communication Theory and Research, Third Edition, 2019.

[16] S. L. Jarvenpaa and D. E. Leidner, "Communication and Trust in Global Virtual Teams," J. Comput. Commun., 2006.

[17] J. M. McCormick, “Diplomatic History,” in Routledge Handbook of American Foreign Policy, 2015.

[18] T. Koch, "Journalism or public relations? A quantitative survey of custom publishing editors in Germany," Public Relat. Rev., 2016.

[19]P. T. Metaxas and J. De Stefano, "Web spam, propaganda and trust," in Proceedings of the 1st International Workshop on Adversarial Information Retrieval on the Web, AIRWeb 2005 - Held in Conjunction with the 14th International World Wide Web Conference, 2005.

[20]D. Collector and F. G. Module, "Qualitative Research Methods Overview," Qual. Res. Methods A Data Collect. F. Guid., 2011.

[21] A. K. Harrison, "Ethnography,” Oxford Handb. Qual. Res., pp. 223-253, 2014.

[22] J. A. Maxwell and L. E. Reybold, "Qualitative Research," in International Encyclopedia of the Social \& Behavioral Sciences: Second Edition, 2015.

[23] S. J. Tracy, "Qualitative quality: Eight a"big-tent" criteria for excellent qualitative research," Qual. Inq., 2010.

[24]J. D. Douglas, Investigative Social Research: Individual and Team Field Research. Sage Beverly Hills, CA, 1976. 